\title{
Development and Validation of a Method for Simultaneous Determination of Metformin and Saxagliptin in a Formulation by RP-HPLC
}

\author{
P. B. N. Prasad ${ }^{*}$, K. Satyanaryana ${ }^{2}$, G. Krishnamohan ${ }^{3}$ \\ ${ }^{1}$ Central Drugs Testing Laboratory, CDSCO, Hyderabad, India \\ ${ }^{2}$ NATCO Pharma R\&D, Hyderabad, India \\ ${ }^{3}$ Deparment of Pharmacy, JNTUH, Hyderabad, India \\ Email: ${ }^{*}$ pulijala bnprasad@yahoo.com
}

Received 25 August 2015; accepted 11 October 2015; published 14 October 2015

Copyright (C) 2015 by authors and Scientific Research Publishing Inc.

This work is licensed under the Creative Commons Attribution International License (CC BY).

http://creativecommons.org/licenses/by/4.0/

(c) (i) Open Access

\begin{abstract}
A simple, specific, sensitive, precise and accurate reverse phase high performance liquid chromatographic method (RP-HPLC) was developed for the simultaneous analysis of Metformin and Saxagliptin in active pharmaceutical ingredients (APIs) as well as in marketed tablet (combination) dosage forms. The method was achieved on Enable $C_{18} G(250 \times 4.6 \mathrm{~mm} ; 5 \mu \mathrm{m}$ particle size $)$ column using $0.05 \mathrm{M} \mathrm{KH}_{2} \mathrm{PO}_{4}$ buffer (pH 4.5): Methanol:Acetonitrile (60:20:20 \% v/v) as a mobile phase at a flow rate of $0.6 \mathrm{~mL} / \mathrm{min}$ and by employing $\mathrm{UV}$ detection at $220 \mathrm{~nm}$ wavelength. The retention time of Metformin and Saxagliptin were found to be $4.38 \mathrm{~min}$ and $6.92 \mathrm{~min}$, respectively. The method was validated as per ICH guidelines. The limit of detection (LOD) and limit of quantification (LOQ) of Metformin were found to be $0.112 \mu \mathrm{g} / \mathrm{mL}$ and $0.373 \mu \mathrm{g} / \mathrm{mL}$, respectively, while those of Saxagliptin were found to be $0.029 \mu \mathrm{g} / \mathrm{mL}$ and $0.096 \mu \mathrm{g} / \mathrm{mL}$, respectively. The method was found to be rapid, sensitive, linear, specific, accurate, precise and economic for the quality control and stability assays of Metformin and Saxagliptin in marketed tablet dosage forms.
\end{abstract}

\section{Keywords}

Metformin, Saxagliptin, Simultaneous Analysis, RP-HPLC, Stress Induced Degradation

\section{Introduction}

Metformin is an oral antidiabetic drug and is chemically, 1,1-dimethyl biguanide hydrochloride [1]. It has high "Corresponding author.

How to cite this paper: Prasad, P.B.N., Satyanaryana, K. and Krishnamohan, G. (2015) Development and Validation of a Method for Simultaneous Determination of Metformin and Saxagliptin in a Formulation by RP-HPLC. American Journal of Analytical Chemistry, 6, 841-850. http://dx.doi.org/10.4236/ajac.2015.611080 
efficacy, safety profile, beneficial cardiovascular and metabolic effects and it also has therapeutic benefit in assocation with other antidiabetic drugs. Hence this drug is included in first line therapy to treat patients with type 2 diabetes mellitus [2]. The main action of Metformin is to decrease fasting plasma glucose levels and is achieved by suppressing excessive hepatic glucose production and improving glucose clearance. It is the principal component in combination therapies intended for diabetes and is frequently used in high doses of about 500 to 850 $\mathrm{mg}$ [1]. Saxagliptin is also oral antidiabetic drug and is belongs to new dipeptidyl peptidase-4 (DPP-4) inhibitor class of drugs [3]. Chemical name is (1S,3S,5S)-2-[(2S)-2-amino-2-(3-hydroxy-1-adamantyl)acetyl]-2-azabicyclo [3.1.0] hexane-3-carbonitrile [4]. It is used for the treatment of type II diabetes in combination with metformin, a sulphonylurea [3].

The literature survey reveals that several analytical methods are reported for quantitative estimation of Metformin alone in body fluids and in pharmaceutical formulations. Those methods include spectrophotometry, electrochemical methods, HPLC, liquid chromatography-electrospray ionization tandem mass spectrometry and electrophoresis [5]. Several analytical methods are also reported for quantitative estimation of Saxagliptin in body fluids and pharmaceutical formulations, which include HPLC, UV Spectrophotometry, LC-MS and potentiometric methods [4]. Reverse phase high performance liquid chromatographic method (RP-HPLC) for simultaneous estimation of Metformin and Saxagliptin is also reported [3], but in this method the flow rate is 1.5 $\mathrm{mL} / \mathrm{min}$, which will increases the mobile phase consumption and it has not reported the method specificity by conducting stress induced degradation studies.

Hence in this study an attempt was made to develop and validate an economic, rapid reversed-phase high performance liquid chromatographic method for the quality control of Metformin and Saxagliptin, simultaneously, in pharmaceutical preparations with lower solvent consumption along with short analytical run time that leads to an environmentally friendly chromatographic procedure and will also allow the analysis of a large number of samples in a very short period of time. The method was validated and found to be accurate, precise and reproducible.

\section{Materials and Methods}

\subsection{Chemicals and Drugs}

Saxagliptin was obtained as a gift sample from Mylan laboratories Ltd. (Hyderabad, India). Metformin was obtained as a gift sample from Aurobindo Pharmaceuticals Ltd. (Hyderabad, India). Kombiglyze XR (Saxagliptin$5 \mathrm{mg}$ and Metformin-1000 mg) tablets and Onglyza (saxagliptin-5 mg) tablets manufactured by Bristol-Mayerssquibb, (USA) were purchased. Potassium dihydrogen orthophosphate $\left(\mathrm{KH}_{2} \mathrm{PO}_{4}\right)$ of AR grade was purchased from Merck and HPLC grade solvents like Methanol and Acetonitrile were purchased from SD fine chemicals Ltd., India.

\subsection{Equipment}

It consists of Ultra Fast Liquid Chromatograph of Shimadzu (Kyoto, Japan) equipped with binary pump (LC 20AD), UV/Visible detector (LC 20A) and Rheodyne injector port. The output signal was monitored and processed using Lab solutions software. The stationary phase employed is Enable $\mathrm{C}_{18} \mathrm{G}$ column $(250 \times 4.6 \mathrm{~mm}$; 5 $\mu \mathrm{m}$ particle size).

\subsection{Standard Solution Preparation}

Stock solution A was prepared by dissolving accurately weighed Saxagliptin (5 mg) and Metformin (1000 mg) in $100 \mathrm{~mL}$ Methanol, which results in concentration of Saxagliptin and Metformin as $50 \mu \mathrm{g} / \mathrm{mL}$ and 10,000 $\mu \mathrm{g} / \mathrm{mL}$, respectively. From this stock solution $0.4 \mathrm{ml}$ was taken in $10 \mathrm{ml}$ volumetric flask and volume was made up to the mark with Methanol, which results in concentration of Saxagliptin and Metformin as $2 \mu \mathrm{g} / \mathrm{mL}$ and 400 $\mu \mathrm{g} / \mathrm{mL}$, respectively (Stock solution B).

\subsection{Sample Preparation}

Ten tablets of KOMBIGLYZE were weighed and then finely powdered. An accurately weighed portion of the powder equivalent to $2000 \mathrm{mg}$ of Metformin and $10 \mathrm{mg}$ of Saxagliptin was transferred to $100 \mathrm{~mL}$ volumetric 
flask and $50 \mathrm{ml}$ Methanol was added and sonicated for $25 \mathrm{~min}$. Then the volume was made up to $100 \mathrm{ml}$ with Methanol and was filtered. Serial dilutions were made from this solution to obtain required concentrations.

\section{HPLC Method Development}

Solubility profiles of the drugs were taken into consideration for the selection of solvent system. Saxagliptin was sparingly soluble in water and soluble in Methanol, Acetonitrile, $\mathrm{KH}_{2} \mathrm{PO}_{4}$ buffer:Methanol (60:40 \%v/v), Acetonitrile:Methanol (50:50 \%v/v) while Metformin shows good solubility in all solvents. Solubility data of Saxagliptin and Metformin were shown in Table 1. Multiple trials were done for the development of an HPLC method for simultaneous analysis of Saxagliptin and Metformin. Various solvent mixtures were tried at different flow rates. Like $0.02 \mathrm{M} \mathrm{KH}_{2} \mathrm{PO}_{4}$ buffer ( $\left.\mathrm{pH} 4.5\right)$ :Acetonitrile $(80: 20 \% \mathrm{v} / \mathrm{v})$ with a flow rate $1 \mathrm{~mL} / \mathrm{min}, 0.05 \mathrm{M}$ $\mathrm{KH}_{2} \mathrm{PO}_{4}$ buffer (pH: 4.5):Methanol (70:30\%v/v) with a flow rate of $1 \mathrm{~mL} / \mathrm{min}, 0.05 \mathrm{M} \mathrm{KH}_{2} \mathrm{PO}_{4}$ buffer $(\mathrm{pH}$ 4.5):Methanol (60:40 \%v/v) with flow rate of $1 \mathrm{~mL} / \mathrm{min}$, etc. Trials were continued till the method was optimized.

\section{Assay of Saxagliptin and Metformin in Formulation by HPLC}

Standard and sample solutions of Saxagliptin and Metformin (in combination) were injected and chromatograms were recorded at $220 \mathrm{~nm}$ with UV detector. The percentage assay is given by the following formula:

$$
\text { \%Assay }=\frac{\mathrm{At}}{\mathrm{As}} \times \frac{\mathrm{Ws}}{\mathrm{Ds}} \times \frac{\mathrm{Dt}}{\mathrm{Wt}} \times \frac{\mathrm{P}}{100} \times \frac{\text { avg.weight }}{\text { label claim }} \times 100
$$

where,

At $=$ Peak area of sample preparation.

As $=$ Peak area of standard preparation .

Ws $=$ Weight of working standard taken in $\mathrm{mg}$.

$\mathrm{Wt}=$ Weight of sample taken in $\mathrm{mg}$.

$\mathrm{Dt}=$ Sample dilution.

Ds $=$ Standard dilution .

$\mathrm{P}=$ Percentage purity of working standard.

\section{Method Validation}

Analytical method validation was performed as per the ICH guidelines [6]. The developed method was validated for the various parameters like specificity, linearity, limit of detection (LOD), limit of quantification (LOQ), accuracy, precision and robustness.

\subsection{Specificity}

Specificity is the ability to assess unequivocally the analyte in the presence of components which may be expected to be present. Typically these might include impurities, degradants, matrix, etc. It can be performed by various methods and among them one is analyzing the sample after subjecting to degradation studies, which results in analyte degradation up to $10 \%$ to $30 \%$. The Forced Degradation studies were performed by exposing drug solution to stress conditions like acidic $(0.1 \mathrm{~N} \mathrm{HCl}, 1 \mathrm{~N} \mathrm{HCl})$, basic $(0.1 \mathrm{~N} \mathrm{NaOH}, 1 \mathrm{~N} \mathrm{NaOH})$, peroxide $\left(\mathrm{H}_{2} \mathrm{O}_{2} 3 \% \mathrm{v} / \mathrm{v}\right)$ and photo induced degradation (direct sunlight for $24 \mathrm{Hrs}$ ). The resulting solutions were analyzed for analyte peak and unknown degradants generated by stress induced degradation.

Table 1. Saxagliptin and metformin solubility data.

\begin{tabular}{ccccc}
\hline & \multicolumn{3}{c}{ Solvents/Solvents Mixture } \\
\hline Drugs & Water & Methnaol & Acetonitrile & $\begin{array}{c}\mathrm{KH}_{2} \mathrm{PO}_{4} \text { buffer: } \\
\text { Methanol }(60: 40 \% \mathrm{v} / \mathrm{v})\end{array}$ \\
\hline Saxagliptin & Sparingly soluble & Soluble & Soluble & Soluble \\
Metformin & Soluble & Soluble & Soluble & Soluble \\
\hline
\end{tabular}




\subsubsection{Acid Induced Degradation}

Stock solution of concentration $100 \mu \mathrm{g} / \mathrm{mL}(2 \mathrm{~mL})$ was added to $2 \mathrm{~mL}$ of $0.1 \mathrm{~N} \mathrm{HCl}$ in a $10 \mathrm{~mL}$ volumetric flask and stock solution of $100 \mu \mathrm{g} / \mathrm{mL}$ ( $2 \mathrm{~mL}$ ) was added to $2 \mathrm{~mL}$ of $1 \mathrm{~N} \mathrm{HCl}$ in $10 \mathrm{~mL}$ volumetric flask. The resultant solution was refluxed for $1 \mathrm{~h}$ at $80^{\circ} \mathrm{C}$. The samples were cooled to room temperature, neutralized and diluted to the volume with Methanol.

\subsubsection{Alkali Induced Degradation}

Stock solution $100 \mu \mathrm{g} / \mathrm{mL}(2 \mathrm{~mL}$ ) was added to $2 \mathrm{~mL}$ of $0.1 \mathrm{~N} \mathrm{NaOH}$ in a $10 \mathrm{~mL}$ volumetric flask. And stock solution of $100 \mu \mathrm{g} / \mathrm{mL}(2 \mathrm{~mL}$ ) was added to $2 \mathrm{~mL}$ of $1 \mathrm{~N} \mathrm{NaOH}$ in $10 \mathrm{~mL}$ volumetric flask The resultant solution was refluxed for $1 \mathrm{hr}$ at $80^{\circ} \mathrm{C}$. The samples were cooled to room temperature, neutralized and diluted to the volume with methanol.

\subsubsection{Peroxide Induced Degradation}

Stock solution, $2 \mathrm{~mL}$, was added to $2 \mathrm{~mL}$ of $\mathrm{H}_{2} \mathrm{O}_{2}(3 \% \mathrm{v} / \mathrm{v})$ in a $10 \mathrm{ml}$ volumetric flask. The resultant solution was refluxed for $1 \mathrm{~h}$ at $80^{\circ} \mathrm{C}$. Dilute the solution with methanol.

\subsubsection{Photolytic Degradation}

Stock solution, $2 \mathrm{~mL}$, was added to $2 \mathrm{~mL}$ of Methanol in a $10 \mathrm{~mL}$ of volumetric flask and the resultant solution was exposed to direct sunlight for 1 day $(24 \mathrm{~h})$.

\subsubsection{Linearity}

Linearity studies should covered the range of $0 \%-150 \%$ of the expected level of the analyte. Different concentration solutions of Saxagliptin (0.2, 0.4, 0.6, 0.8, 1.0 and $1.2 \mu \mathrm{g} / \mathrm{mL})$ and Metformin (40, 80, 120, 160, 200, 240 $\mu \mathrm{g} / \mathrm{mL}$ ) were prepared from the stock solution using Methanol as diluent. The calibration curve was obtained by plotting peak area vs. concentration, using the least squares method. ICH recommends that, for the establishment of linearity, a minimum of five concentrations should normally be used. Acceptance criteria is correlation coefficient should be not less than 0.998 .

\subsection{Limit of Detection (LOD)}

The detection limit of an individual analytical procedure is the lowest amount of analyte in a sample which can be detected but not necessarily quantified as an exact value. LOD was calculated using the following formula:

$$
\mathrm{LOD}=3.3 \sigma / \mathrm{S}
$$

where $\sigma$ is the standard deviation of the response and $S$ is the slope of the calibration curve.

The Limit of detection (LOD) for Saxagliptin and for Metformin are determined.

\subsection{Limit of Quantification (LOQ)}

The quantification limit of an individual analytical procedure is the lowest amount of analyte in a sample which can be quantitatively determined with suitable precision and accuracy. LOQ was calculated using the following formula;

$$
\mathrm{LOQ}=10 \sigma / S
$$

where $\sigma$ is the standard deviation of the response and $S$ is the slope of the calibration curve.

The limit of quantification for Saxagliptin and for Meftormin are determined.

\subsection{Accuracy}

Accuracy is calculated as the percentage of recovery by the assay of known added amount of analyte in the sample, or as the difference between the mean and the accepted true value, together with the confidence intervals. ICH documents recommend that accuracy should be assessed using a minimum of nine determinations i.e., three replicates at three concentrations across the specified range of the procedure. Acceptance criteria is the mean \% recovery at each spiked level should be not less than $98 \%$ and not more than $102 \%$. 


\subsection{Precision}

The precision of an analytical procedure is usually expressed as the variance, standard deviation or coefficient of variation of a series of measurements. It can be determined by measuring repeatability, intermediate precision and reproducibility. ICH guidelines recommend that repeatability should be assessed using a minimum of nine determinations covering the specified range of the procedure (i.e., three replicates of three concentrations) or using a minimum of six determinations at $100 \%$ of the test concentration. Acceptance criteria are \% RSD of the peak areas and \%assay of six injections should be not more than $2.0 \%$.

\subsection{Robustness}

The robustness of an analytical procedure is a measure of its capacity to remain unaffected by small, but deliberate variations in method parameters and provides an indication of its reliability during normal usage. The variable method parameters may involve small variations such as temperature $\left( \pm 5^{\circ} \mathrm{C}\right), \mathrm{KH}_{2} \mathrm{PO}_{4}$ buffer $\mathrm{pH}( \pm 0.5)$, ionic strength of buffers, level of additives to mobile phase, flow rate $( \pm 0.2 \mathrm{~mL} / \mathrm{min})$, wavelength $( \pm 2 \mathrm{~nm})$. Acceptance criteria are \%RSD of peak areas and \%assay of main peaks should be not more than $2.0 \%$.

\section{Results and Discussion}

\subsection{HPLC Method Development}

During the trials with $0.02 \mathrm{M} \mathrm{KH}_{2} \mathrm{PO}_{4}$ buffer ( $\mathrm{pH}$ 4.5):Acetonitrile (80:20 \%v/v) mobile phase with a flow rate 1 $\mathrm{mL} / \mathrm{min}$, resulted in single Metformin peak and no Saxagliptin peak was observed. $0.05 \mathrm{M} \mathrm{KH}_{2} \mathrm{PO}_{4}$ buffer (pH: 4.5):Methanol $(70: 30 \% \mathrm{v} / \mathrm{v})$ with a flow rate of $1 \mathrm{~mL} / \mathrm{min}$, resulted in no resolution between Metformin and Saxagliptin peaks. $0.05 \mathrm{M} \mathrm{KH}_{2} \mathrm{PO}_{4}$ buffer ( $\mathrm{pH} 4.5$ ):Methanol (60:40 \%v/v) with flow rate of $1 \mathrm{~mL} / \mathrm{min}$ was resulted in fronting and broadening of Saxagliptin peak. Hence further trials were continued and at last an optimized method was developed, which employs $0.05 \mathrm{M} \mathrm{KH}_{2} \mathrm{PO}_{4}$ buffer ( $\mathrm{pH}$ 4.5):Methanol:Acetonitrile (60: 20:20 \% v/v) as mobile phase with a flow rate of $0.6 \mathrm{~mL} / \mathrm{min}$. The optimized chromatographic conditions were shown in Table 2. The standard solution (Metformin and Saxagliptin) was analyzed by the developed HPLC method and the chromatogram in both normalized and zoom conditions was shown in Figure 1(a) and Figure 1(b), respectively. The retention time of (Rt) Metformin and Saxagliptin were found as 4.3 min and 6.9 min, respectively.

\subsection{Assay of Formulation}

The standard and test solutions of Metformin and Saxagliptin were analyzed by the HPLC method and the chromatograms were shown in Figure 2(a) and Figure 2(b), respectively. The \% assay of Metformin and Saxagliptin were found to be $99.66 \%$ and $99.04 \%$, respectively. As the \% assay results were found to be within the limits i.e., $98 \%$ - 102\% for both the drugs, the developed method can be routinely used for the simultaneous estimation of Metformin and Saxagliptin in the formulations.

Table 2. Chromatographic conditions.

$\begin{array}{lc}\text { Column } & \text { Enable } \mathrm{C} 18 \mathrm{G}(250 \times 4.6 \mathrm{~mm} ; 5 \mu \mathrm{m} \text { particle size }) \\ \text { Elution method } & \text { Isocratic } \\ \text { Mobile Phase } & 0.05 \mathrm{M} \mathrm{KH}_{2} \mathrm{PO}_{4} \text { buffer }(\mathrm{pH} 4.5): \text { Methanol:Acetonitrile }(60: 20: 20 \% \mathrm{v} / \mathrm{v}) \\ \text { Flow rate } & 0.6 \mathrm{ml} / \mathrm{min} \\ \text { Column temperature } & 25^{\circ} \mathrm{C} \\ \text { Volume of injection } & 10 \mu \mathrm{L} \\ \text { Detector } & \mathrm{UV} \\ \text { Detection wavelength } & 220 \mathrm{~nm} \\ \text { Run time } & 10 \mathrm{~min} \\ \text { Diluent } & \text { Methanol (HPLC grade) }\end{array}$




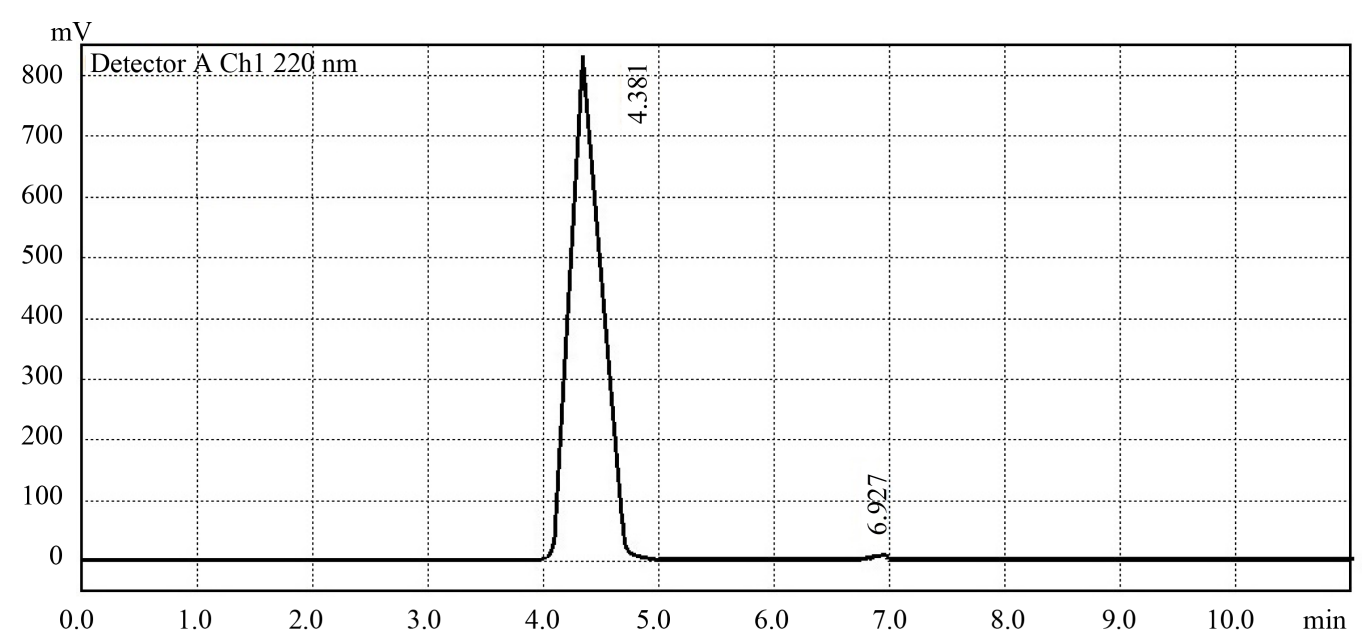

(a)

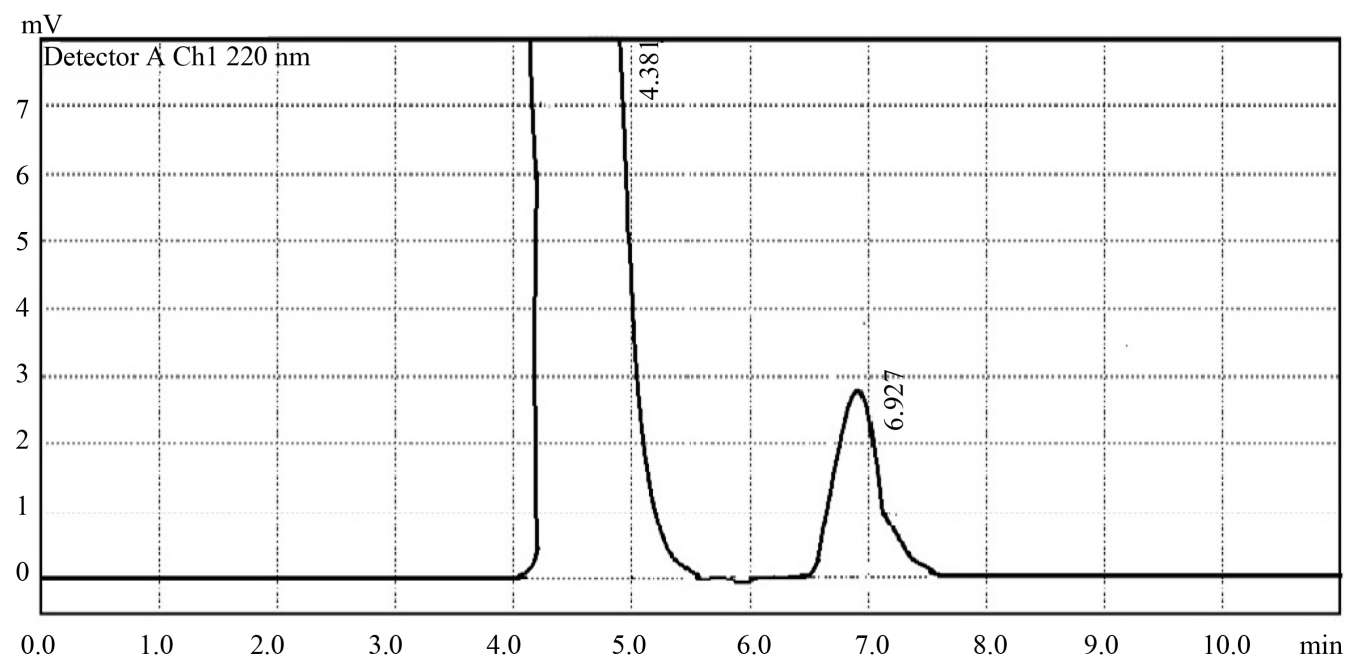

(b)

Figure 1. Chromatogram of metformin and saxagliptin (a) Normalized; (b) Zoom.

\subsection{HPLC Method Validation}

As per ICH guidelines the method was validated for various parameters which includes Specificity, Linearity, LOD, LOQ, Accuracy, Precision and Robustness.

\subsubsection{Specificity}

The results of stress induced degradation studies of Metformin and Saxagliptin were shown in Table 3. Though the stress conditions adopted were degraded the drug up to $10 \%$ to $30 \%$ with less relative standard deviation, the degradent peaks were not interfering the peaks corresponding to the active components. By these results the method was proved to be selective and suitable for routine quality control analysis.

\subsubsection{Linearity}

Calibration curves of Metformin and Saxagliptin were plotted using peak area vs. concentration and were shown in Figure 3(a) and Figure 3(b), respectively. Linearity was found in the range of $0.2-1.2 \mu \mathrm{g} / \mathrm{mL}$ for Saxagliptin and $40-240 \mu \mathrm{g} / \mathrm{mL}$ for Metformin. Saxagliptin and Metformin correlation coefficient values were found to be 0.999 and 0.998 , respectively. As per ICH guidelines these values were within acceptable limit and hence the method was found to be linear. 

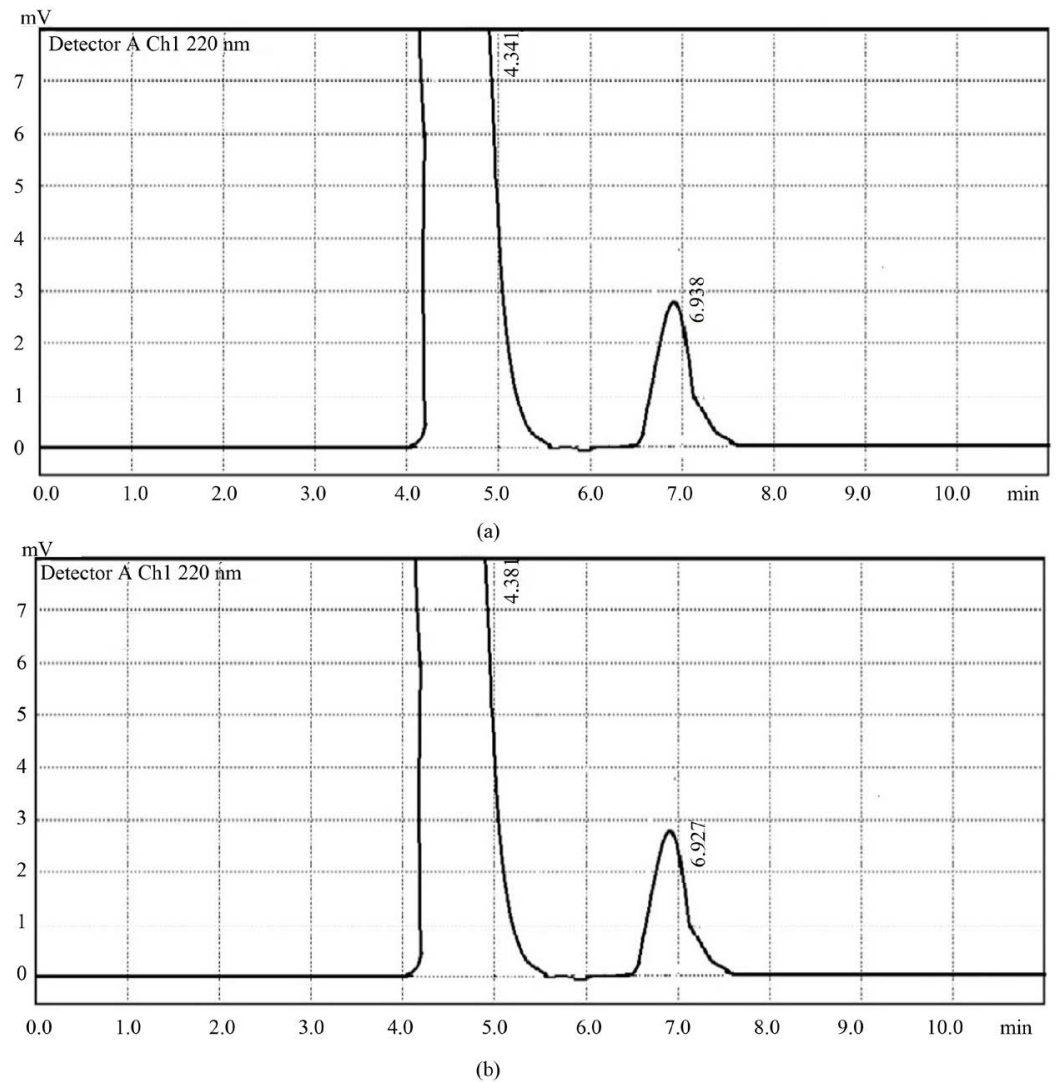

Figure 2. Chromatogram of (a) Standard and (b) Test solutions of metformin and saxagliptin.

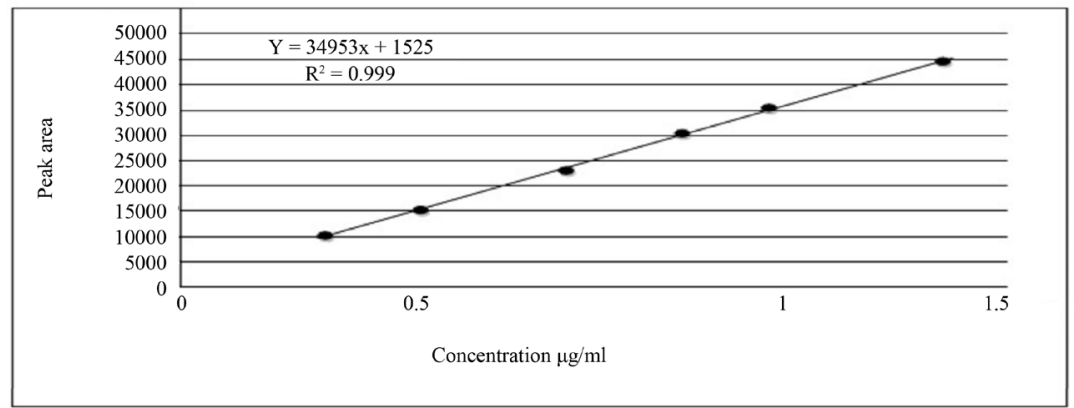

(a)

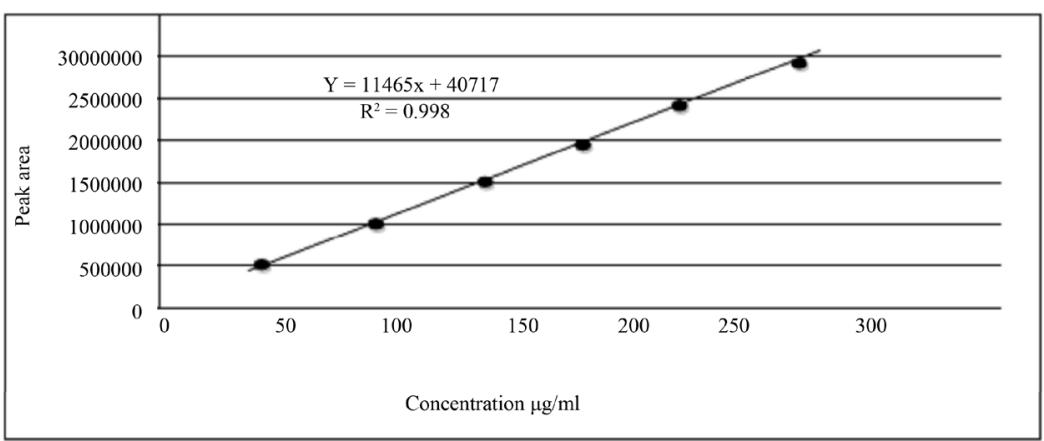

(b)

Figure 3. Calibration of curves of (a) Saxagliptin (b) Metformin. 


\subsubsection{LOD and LOQ}

The lowest possible concentrations of Saxagliptin that can be detected and quantified by the present method were found to be $0.029 \mu \mathrm{g} / \mathrm{mL}$ and $0.096 \mu \mathrm{g} / \mathrm{mL}$, respectively while that of Metformin were found to be 0.112 $\mu \mathrm{g} / \mathrm{mL}$ and $0.373 \mu \mathrm{g} / \mathrm{mL}$, respectively. The low values of LOD and LOQ indicates that the method can be used for detection and quantification of Metformin and Saxagliptin combination formulation over a very wide range of concentrations.

\subsubsection{Accuracy}

Mean percentage recovery values at three different concentrations of Saxagliptin and Metformin were calculated. The results of accuracy study of Metformin and Saxagliptin were shown in Table 4 and Table 5, respectively. In accuracy study \% recovery of Saxagliptin and Metformin at each level was within the limits of $98 \%$ - 102\%. Hence, accuracy was established for the developed work and the method was found to be accurate.

\subsubsection{Precision}

Intra- and inter-day precision study results of both Metformin and Saxagliptin were shown in Table 6. \% RSD values of Saxagliptin and Metformin in both intra- and inter-day precision studies were found to be less than 2, which were within the limits mentioned by ICH guidelines. Hence the method was found to be precise.

\subsubsection{Robustness}

Mobile phase flow rate was slightly altered by 0.2 units $(0.4 \mathrm{~mL} / \mathrm{min}$ and $0.8 \mathrm{~mL} / \mathrm{min})$. The \%RSD in Metformin and Saxagliptin peak areas was calculated and the values were shown in Table 7 . The \% RSD values were found to be not more than $2.0 \%$ for variation in flow rate. According to ICH guidelines the \%RSD should be less than 2 and hence the method was found to be robust.

\section{Conclusion}

The present work was planned for the simultaneous analysis of Metformin and Saxagliptin in active pharmaceutical ingredients (APIs) as well as in marketed tablet dosage forms, both qualitatively and quantitatively.

Table 3. Degradation study of metformin and saxagliptin.

\begin{tabular}{cccc}
\hline \multirow{2}{*}{$\begin{array}{c}\text { Conditions applied for the standard solution } \\
0.1 \mathrm{~N} \mathrm{HCl} \text { at } 80^{\circ} \mathrm{C} \text { temp }\end{array}$} & Time $(\mathrm{h})$ & \multicolumn{2}{c}{$\%$ of active drug present after degradation \pm RSD } \\
\cline { 3 - 4 } & & Metformin & Saxagliptin \\
\hline $1 \mathrm{~N} \mathrm{HCl}$ at $80^{\circ} \mathrm{C}$ temp & 1 & $75.29 \pm 1.7$ & $73.87 \pm 1.5$ \\
$0.1 \mathrm{~N} \mathrm{NaOH}$ at $80^{\circ} \mathrm{C}$ temp & 1 & $78.34 \pm 1.9$ & $42.87 \pm 2.1$ \\
$3 \% \mathrm{H}_{2} \mathrm{O}_{2}$ & 1 & $67.69 \pm 1.8$ & $76.64 \pm 1.3$ \\
Photolytic degradation (sunlight) & 1 & $81.43 \pm 1.2$ & $90.34 \pm 1.4$ \\
\hline
\end{tabular}

Table 4. Accuracy study of metformin.

\begin{tabular}{|c|c|c|c|c|c|c|}
\hline Recovery level & $\begin{array}{l}\text { Sample } \\
(\mu \mathrm{g} / \mathrm{mL})\end{array}$ & $\begin{array}{l}\text { Standard } \\
(\mu \mathrm{g} / \mathrm{mL})\end{array}$ & $\begin{array}{l}\text { Amount found } \\
\qquad(\mu \mathrm{g} / \mathrm{mL})\end{array}$ & \% Recovery & $\begin{array}{c}\text { Mean } \\
(\%) \pm S D\end{array}$ & $\begin{array}{c}\% \\
\text { RSD }\end{array}$ \\
\hline $50 \%$ & 80 & 40 & $\begin{array}{l}119.01 \\
119.93 \\
120.02\end{array}$ & $\begin{array}{c}99.17 \\
99.42 \\
100.01\end{array}$ & $99.706 \pm 0.466$ & 0.467 \\
\hline $100 \%$ & 80 & 80 & $\begin{array}{l}161.05 \\
159.70 \\
158.26\end{array}$ & $\begin{array}{c}100.65 \\
99.81 \\
98.91\end{array}$ & $99.79 \pm 0.870$ & 0.872 \\
\hline $150 \%$ & 80 & 120 & $\begin{array}{l}198.01 \\
199.58 \\
196.63\end{array}$ & $\begin{array}{l}99.00 \\
99.78 \\
98.31\end{array}$ & $99.03 \pm 0.735$ & 0.743 \\
\hline
\end{tabular}


Table 5. Accuracy study of saxagliptin.

\begin{tabular}{|c|c|c|c|c|c|c|}
\hline $\begin{array}{l}\text { Recovery } \\
\text { level }\end{array}$ & $\begin{array}{l}\text { Sample } \\
(\mu \mathrm{g} / \mathrm{mL})\end{array}$ & $\begin{array}{l}\text { Standard } \\
(\mu \mathrm{g} / \mathrm{mL})\end{array}$ & $\begin{array}{l}\text { Amount found } \\
(\mu \mathrm{g} / \mathrm{mL})\end{array}$ & \% Recovery & Mean $(\%) \pm S D$ & \% RSD \\
\hline $50 \%$ & 0.4 & 0.4 & $\begin{array}{l}0.598 \\
0.599 \\
0.602\end{array}$ & $\begin{array}{c}99.66 \\
99.83 \\
100.33\end{array}$ & $99.94 \pm 0.348$ & 0.348 \\
\hline $100 \%$ & 0.4 & 0.6 & $\begin{array}{l}0.813 \\
0.796 \\
0.804\end{array}$ & $\begin{array}{c}101.62 \\
99.50 \\
100.52\end{array}$ & $100.54 \pm 1.061$ & 1.055 \\
\hline $150 \%$ & 0.4 & 0.8 & $\begin{array}{l}0.995 \\
1.014 \\
0.988\end{array}$ & $\begin{array}{c}99.59 \\
101.40 \\
98.87\end{array}$ & $99.95 \pm 1.304$ & 1.304 \\
\hline
\end{tabular}

Table 6. Intra- and Inter-day precision study of metformin and saxagliptin.

\begin{tabular}{|c|c|c|c|c|c|}
\hline \multicolumn{3}{|c|}{ Metformin } & \multicolumn{3}{|c|}{ Saxagliptin } \\
\hline \multirow[b]{2}{*}{ Concentration } & \multicolumn{2}{|c|}{ \% RSD } & \multirow[b]{2}{*}{ Concentration } & \multicolumn{2}{|c|}{ \%RSD } \\
\hline & $\begin{array}{l}\text { Intra-day } \\
\text { Precision }\end{array}$ & $\begin{array}{l}\text { Inter-day } \\
\text { Precision }\end{array}$ & & Intra-day Precision & $\begin{array}{l}\text { Inter-day } \\
\text { Precision }\end{array}$ \\
\hline 80 & 0.167 & 0.144 & 0.4 & 0.452 & 1.329 \\
\hline 120 & 1.453 & 0.572 & 0.6 & 0.546 & 0.698 \\
\hline 160 & 0.319 & 1.396 & 0.8 & 0.871 & 0.468 \\
\hline
\end{tabular}

Table 7. Robustness of the method.

\begin{tabular}{lccc}
\hline Parameters & Normal condition & Condition opted & MRSD \\
\cline { 3 - 3 } Flow rate & $0.6 \mathrm{~mL} / \mathrm{min}$ & $0.4 \mathrm{~mL} / \mathrm{min}$ & 0.745 \\
& & $0.8 \mathrm{~mL} / \mathrm{min}$ & $0.338 \quad 0.962$ \\
\hline
\end{tabular}

Reverse phase high performance liquid chromatographic method (RP-HPLC), which was developed and validated in the present work was found to be simple, specific, linear, precise, reproducible, accurate and rapid. The mobile phase used here is simple to prepare as well as economical. Hence, this method is reliable and convenient for routine quality control analysis and stability assays of Metformin and Saxagliptin in marketed tablet dosage forms.

\section{Acknowledgements}

Authors are thankful to Mylan laboratories Ltd. (Hyderabad, India) and Aurobindo Pharmaceuticals Ltd. (Hyderabad, India) for the kind gift of Saxagliptin and Metformin, respectively.

\section{References}

[1] Havele, S. and Dhaneshwar, S. (2010) Development and Validation of a HPLC Method for the Determination of Metformin Hydrochloride, Gliclazide and Piogliglitazone Hydrochloride in Multicomponent Formulation. Webmed Central Pharmaceutical Sciences, 1, Article ID: WMC001078.

[2] Rojas, L.B.A. and Gomes, M.B. (2013) Metformin: An Old but Still the Best Treatment for Type 2 Diabetes. Diabetology and Metabolic Syndrome, 5, 1-15. http://dx.doi.org/10.1186/1758-5996-5-6

[3] Pravin Kumar, R., Vasudevan, M. and Deecaraman (2012) A Validated RP-HPLC Method for Simultaneous Estimation of Metformin and Saxagliptin in Tablets. Rasayan Journal Chemistry, 5, 137-141.

[4] Srinivasa Rao, P., Rama Chandran, D., Murali, K. and Srinivasu, S. (2013) Stability Indicating Isocratic Reverse Phase 
HPLC Method with PDA Detector for the Estimation of Saxagliptin in Bulk Drugs and in Its Formulation. International Journal of Pharma Sciences, 3, 333-342.

[5] Murthy, T.G.K. and Geethanjali, J. (2014) Development of a Validated RP-HPLC Method for Simultaneous Estimation of Metformin Hydrochloride and Rosuvastatin Calcium in Bulk and In-House Formulation. Journal of Chromatography and Separation Techniques, 5, 1-7.

[6] ICH Harmonised Tripartite Guideline (2005) Validation of Analytical Procedures: Text and Methodology Q2(R1). International Conference on Harmonisation of Technical Requirements for Registration of Pharmaceuticals for Human Use, Geneva, 1-13. 